\section{Calcium and Phosphorus Influence Creeping Bentgrass and Annual Bluegrass Growth in Acidic Soils}

\section{S. Kuo \\ Washington State University Research and Extension Center, Puyallup, WA $98371-4998$}

Additional index words. gypsum, exchangeable calcium, extractable phosphorus, clipping yield, phosphorus uptake

\begin{abstract}
Acidifying soil to prevent annual bluegrass (Poa annua L.) from infesting creeping bentgrass (Agrostis palustris Hud.) reduces soil $\mathbf{P}$ and $\mathrm{Ca}$ availability. This study examined $\mathrm{Ca}$ and $\mathrm{P}$ effects on the growth of these two grasses in four moderately acidic soils using $\mathrm{CaSO}_{4}$ as a Ca source. Each soil received four $P$ rates $\left(0,10,40\right.$, or $\left.80 \mathrm{mg} \cdot \mathrm{kg}^{-1}\right)$ and three Ca (as $\left.\mathrm{CaSO}_{4}\right)$ rates $\left(0,400\right.$, or $\left.800 \mathrm{mg} \cdot \mathrm{kg}^{-1}\right)$. Neither Ca nor P treatments substantially changed $\mathbf{p H}$ or exchangeable soil Al. Clipping yields, tissue $\mathbf{P}$ concentration, and $\mathbf{P}$ uptake of both grasses were affected by soil $\mathrm{NaHCO}_{3}-\mathrm{P}$ levels. Compared to bentgrass, annual bluegrass had higher clipping yields and $\mathbf{P}$ uptake at high $\mathbf{P}$ rates or high $\mathrm{NaHCO}_{3}-\mathrm{P}$ levels; this result indicates that annual bluegrass was as acid-tolerant as the bentgrass, provided that available $\mathrm{P}$ in the soil is adequate. Adding $\mathrm{CaSO}_{4}$ to the Papac soil, which contained the least amount of exchangeable Ca among the four soils, markedly enhanced the clipping tissue $P$ concentration and $P$ uptake of creeping bentgrass but not those of annual bluegrass; this result indicates that a differential response to Ca existed between the two grasses. Maintaining an adequate soil $\mathrm{Ca}$ availability was necessary to improve bentgrass growth, particularly for the acid soil containing low available Ca initially.
\end{abstract}

Applying $\mathrm{S}$ is often recommended to prevent annual bluegrass from infesting creeping negatively to $\mathrm{S}$ and soil acidity (Goss et al., 1975; Varco and Sartain, 1986). Soil acidification, however, reduces available $\mathrm{P}$ and $\mathrm{Ca}$ and increases Al volubility. Since Ca stimulates P use (Miller et al., 1972), it is desirable to understand the association of soil $\mathrm{Ca}$ availability and the differential growth behavior of ences in $\mathrm{Ca}$ requirement among bluegrass cultivars have been observed (Nittler and Kenny, 1972).

Calcium carbonate or hydroxide is customarily used as a $\mathrm{Ca}$ source in plant growth studies. However, the consequent effect on $\mathrm{pH}$ and $\mathrm{Al}$ solubility makes it difficult to isolate the specific $\mathrm{Ca}$ effect. Calcium sulfate is a useful alternative because it increases $\mathrm{Ca}$ availability without substantially changing soil $\mathrm{pH}$ (Alva et al., 1990; Perkins and Kaihulla, 1981). Heavy $\mathrm{CaSO}_{4}$ surface applications and extensive leaching for a lengthy period, however, could substantially reduce exchangeable soil Al (Pavan et al., 1984). The objectives of this study were to evaluate the effects of $\mathrm{Ca}$ and $\mathrm{P}$ on clipping yields, tissue $\mathrm{P}$ concentration, and

Received for publication 21 July 1992. Accepted for publication 8 Feb. 1993. Scientific paper no: 01-59, Dept. of Crop and Soil Sciences, College of Agriculture and Home Economics Research Center, Washington State Univ., Pullman. The cost of publishing this paper was defrayed in part by the payment of page charges. Under postal regulations, this paper therefore must be marked advertisement solely to indicate this fact.
P uptake of creeping bentgrass and annual bluegrass in four moderately acidic soils using $\mathrm{CaSO}_{4}$ as a $\mathrm{Ca}$ source and to determine if a differential growth response to $\mathrm{Ca}$ exists between annual bluegrass and creeping bentgrass. $\mathrm{cm}$ deep from various locations in western Washington. The soils were air-dried and crushed to pass through a 2-mm sieve. Each soil was mixed thoroughly with $0,10,40$, or 80 $\mathrm{mg} \mathrm{P}\left(\right.$ as $\left.\mathrm{KH}_{2} \mathrm{PO}_{4}\right) / \mathrm{kg}$ of soil and 0,400 , or 800 $\mathrm{mg} \mathrm{Ca}\left(\right.$ as $\left.\mathrm{CaSO}_{4} \cdot 2 \mathrm{H}_{2} \mathrm{O}\right) / \mathrm{kg}$ of soil and placed in cone-shaped pots $(6 \mathrm{~cm}$ inside diameter, 25 $\mathrm{cm}$ long). Each pot was fertilized with $50 \mathrm{mg}$ $\mathrm{K}$ (as $\mathrm{KCl}) / \mathrm{kg}$ of soil and with a nutrient solution that contained $0.26 \mathrm{M} \mathrm{N}$ as $\mathrm{NH}_{4} \mathrm{NO}_{3}$ $(94 \%)$ and $\left(\mathrm{NH}_{4}\right)_{2} \mathrm{SO}_{4}(6 \%), 3.6 \times 10^{5} \mathrm{M} \mathrm{MnCl}_{2}$, $2.6 \times 10^{-4} \mathrm{M} \mathrm{ZnSO}_{4}, 1.2 \times 10^{-4} \mathrm{M} \mathrm{CuSO}_{4}, 6.8 \times$ $10^{-4} \mathrm{M} \mathrm{H}_{3} \mathrm{BO}_{3}, 3.5 \times 10^{-6} \mathrm{M} \mathrm{H}_{3} \mathrm{MoO}_{3}$, and $2.3 \times$ $10^{-2} \mathrm{M} \mathrm{MgSO}_{4}$. One milliliter of the nutrient solution was mixed with $4 \mathrm{ml}$ distilled water and evenly applied to the surface of each pot before pots were seeded with $\approx 80$ seeds of annual bluegrass or Penncross creeping bentgrass. Each treatment was replicated three
Four acid soils were collected from 0 to 30 creeping bentgrass and annual bluegrass.

${ }^{2}$ Bent $=$ bentgrass, blue $=$ bluegrass. bentgrass, because annual bluegrass responds the two grasses in acidic soil. Striking differ- times. The pots were placed in a completely randomized experimental design in a glasshouse controlled at $\approx 21 \pm 2 \mathrm{C}$. Irrigation was applied twice daily with an automatic overhead sprinkler system to maintain the soil moisture content at field capacity $(-33 \mathrm{kpa})$ during the experiment.

Natural lighting was supplemented with metal halide lamps for a 16-h photoperiod with a photon flux density ranging from 500 to 900 $\mu \mathrm{mol} \cdot \mathrm{m}^{-2} \cdot \mathrm{s}^{-1}$, depending on the location on the bench. The position of the pots was rearranged occasionally to minimize the influence of light intensity variability.

Four weeks after seeding, the grasses were clipped 3 to $5 \mathrm{~mm}$ above the soil surface. Clipping was continued twice weekly for 4 more weeks. Clippings were oven-dried at $65 \mathrm{C}$ for $48 \mathrm{~h}$ and accumulated to determine final yield. Subsamples were digested in $\mathrm{H}_{2} \mathrm{SO}_{4} \cdot \mathrm{H}_{2} \mathrm{O}_{2}$ at $400 \mathrm{C}$. Phosphorus concentration was analyzed by calorimetry (Murphy and Riley, 1962) and Ca concentration by atomic absorption spectrophotometry.

Soil samples from each pot were collected after shoots were removed, air-dried, and crushed to pass through a $2-\mathrm{mm}$ sieve. Subsamples were analyzed for $\mathrm{pH}$ (1 soil : 2 water), $1 \mathrm{M} \mathrm{KCl}$-extractable $\mathrm{Al}$ and $\mathrm{Ca}$, and $\mathrm{NaHCO}_{3}$-extractable $\mathrm{P}$ (Olsen and Sommers, 1982). Extractable P was determined by colorimetry (Murphy and Riley, 1962) and extractable $\mathrm{Al}$ and $\mathrm{Ca}$ by atomic absorption spectrophotometry.

$\mathrm{CaSO}_{4}$ and $\mathrm{P}$ fertilizer effects on soil $\mathrm{pH}$ and exchangeable Al. Adding $\mathrm{CaSO}_{4}$ greatly increased the exchangeable soil $\mathrm{Ca}$ levels (Table 1) but affected $\mathrm{pH}$ little $(<0.1 \mathrm{pH}$ unit $)$ (Table 2) in this short-term plant growth study. Others have postulated that the displaced $\mathrm{H}^{+}$ and $\mathrm{OH}$ from the respective specific sorption of $\mathrm{Ca}^{+2}$ and $\mathrm{SO}_{4}^{-2}$ (Alva et al., 1990) are neutralized so that there is no net change of surface potential or $\mathrm{pH}$ (Berry et al., 1990).

Exchangeable soil Al decreased or increased slightly with increasing $\mathrm{CaSO}_{4}$ rates, depending on the soil or grass species (Table 2). The $\mathrm{CaSO}_{4}$ effects on exchangeable soil $\mathrm{Al}$ reported in the literature are inconsistent, ranging from no effect in a short-term (2 months) pot culture study in which $\mathrm{CaSO}_{4}$ was incorporated into the soil (Perkins and Kaihulla, 1981) to a considerable reduction in another study that used heavy $\mathrm{CaSO}_{4}$ applications on the soil surface, followed by extensive leaching daily for 7 months (Pavan et al., 1984). In the present study, with only 2 months of $\mathrm{CaSO}_{4}$ contact with the soils, the resultant $\mathrm{CaSO}_{4}$
Table 1. Effect of $\mathrm{Ca}$ added as $\mathrm{CaSO}_{4}$ on exchangeable $\mathrm{Ca}$ levels of four soils averaged across $\mathrm{P}$ rates for

\begin{tabular}{|c|c|c|c|c|c|c|c|c|}
\hline \multirow{3}{*}{$\begin{array}{l}\text { Ca rate } \\
\left(\mathrm{mg} \cdot \mathrm{kg}^{-1}\right)\end{array}$} & \multicolumn{8}{|c|}{ Soil type } \\
\hline & \multicolumn{2}{|c|}{ Papac } & \multicolumn{2}{|c|}{ Wishkah } & \multicolumn{2}{|c|}{ Calawah } & \multicolumn{2}{|c|}{ Mopang } \\
\hline & Bent $^{z}$ & Blue & Bent & Blue & Bent & Blue & Bent & Blue \\
\hline \multicolumn{9}{|c|}{ Exchangeable $\mathrm{Ca}\left(\mathrm{mg} \cdot \mathrm{kg}^{-1}\right)$} \\
\hline 0 & $116 a^{y}$ & $92 \mathrm{a}$ & $165 \mathrm{a}$ & $118 \mathrm{a}$ & $203 a$ & 185 a & 703 a & $735 a$ \\
\hline 400 & $188 \mathrm{~b}$ & $178 \mathrm{~b}$ & $258 \mathrm{~b}$ & $285 \mathrm{~b}$ & $334 \mathrm{~b}$ & $327 \mathrm{~b}$ & $1073 \mathrm{~b}$ & $1095 \mathrm{~b}$ \\
\hline 800 & $216 \mathrm{c}$ & $194 \mathrm{c}$ & $332 \mathrm{c}$ & $284 \mathrm{~b}$ & $365 \mathrm{c}$ & $390 \mathrm{c}$ & $1308 c$ & $1353 \mathrm{c}$ \\
\hline
\end{tabular}

${ }^{y}$ Mean separation within columns at $P \leq 0.05$. 
Table 2. Effect of $\mathrm{Ca}$ added as $\mathrm{CaSO}_{4}$ on $\mathrm{pH}$ and exchangeable $\mathrm{Al}$ (EA) levels (in milligrams per kilogram) of four soils averaged across $\mathrm{P}$ rates for creeping bentgrass and annual bluegrass.

\begin{tabular}{|c|c|c|c|c|c|c|c|c|c|c|c|c|c|c|c|c|}
\hline \multirow{4}{*}{$\begin{array}{l}\text { Ca rate } \\
\left(\mathrm{mg} \cdot \mathrm{kg}^{-1}\right)\end{array}$} & \multicolumn{16}{|c|}{ Soil type } \\
\hline & \multicolumn{4}{|c|}{ Papac } & \multicolumn{4}{|c|}{ Wishkah } & \multicolumn{4}{|c|}{ Calawah } & \multicolumn{4}{|c|}{ Mopang } \\
\hline & \multicolumn{2}{|c|}{ Bentgrass } & \multicolumn{2}{|c|}{ Bluegrass } & \multicolumn{2}{|c|}{ Bentgrass } & \multicolumn{2}{|c|}{ Bluegrass } & \multicolumn{2}{|c|}{ Bentgrass } & \multicolumn{2}{|c|}{ Bluegrass } & \multicolumn{2}{|c|}{ Bentgrass } & \multicolumn{2}{|c|}{ Bluegrass } \\
\hline & $\overline{\mathrm{pH}}$ & EA & $\mathrm{pH}$ & $\overline{\mathrm{EA}}$ & $\overline{\mathrm{pH}}$ & EA & $\mathrm{pH}$ & $\overline{E A}$ & $\mathrm{pH}$ & EA & $\mathrm{pH}$ & EA & $\mathrm{pH}$ & EA & $\mathrm{pH}$ & EA \\
\hline 0 & 5.00 & 167 & 4.92 & 176 & 4.95 & 159 & 4.91 & 200 & 5.14 & 148 & 5.11 & 150 & 4.93 & 434 & 4.92 & 509 \\
\hline 400 & 4.90 & 182 & 4.90 & 163 & 4.96 & 163 & 4.99 & 178 & 5.21 & 137 & 5.10 & 140 & 4.87 & 381 & 4.83 & 472 \\
\hline 800 & 4.92 & 173 & 4.88 & 163 & 4.91 & 195 & 4.88 & 167 & 5.17 & 135 & 5.09 & 149 & 4.83 & 364 & 4.79 & 439 \\
\hline $\mathrm{LSD}_{0.05}$ & 0.06 & 16.9 & 0.06 & 15.8 & 0.06 & 27.3 & 0.08 & 11.9 & 0.05 & 7.5 & 0.06 & 9.4 & 0.05 & 30.3 & 0.04 & 19.0 \\
\hline
\end{tabular}

Table 3. Effect of $\mathrm{P}$ on $\mathrm{pH}$ and exchangeable Al (EA) levels (in milligrams per kilogram) of four soils averaged across Ca rates for creeping bentgrass and annual bluegrass.

\begin{tabular}{|c|c|c|c|c|c|c|c|c|c|c|c|c|c|c|c|c|}
\hline \multirow{4}{*}{$\begin{array}{l}\text { P rate } \\
\left(\mathrm{mg}^{\circ} \mathrm{kg}^{-1}\right)\end{array}$} & \multicolumn{16}{|c|}{ Soil type } \\
\hline & \multicolumn{4}{|c|}{ Papac } & \multicolumn{4}{|c|}{ Wishkah } & \multicolumn{4}{|c|}{ Calawah } & \multicolumn{4}{|c|}{ Mopang } \\
\hline & \multicolumn{2}{|c|}{ Bentgrass } & \multicolumn{2}{|c|}{ Bluegrass } & \multicolumn{2}{|c|}{ Bentgrass } & \multicolumn{2}{|c|}{ Bluegrass } & \multicolumn{2}{|c|}{ Bentgrass } & \multicolumn{2}{|c|}{ Bluegrass } & \multicolumn{2}{|c|}{ Bentgrass } & \multicolumn{2}{|c|}{ Bluegrass } \\
\hline & $\mathrm{pH}$ & $\overline{E A}$ & $\mathrm{pH}$ & EA & $\mathrm{pH}$ & EA & $\mathrm{pH}$ & EA & $\mathrm{pH}$ & $\mathrm{EA}$ & $\mathrm{pH}$ & $\mathrm{EA}$ & $\mathrm{pH}$ & EA & $\mathrm{pH}$ & $\overline{\mathrm{EA}}$ \\
\hline$\overline{0}$ & 4.84 & 170 & 4.78 & 166 & 4.72 & 180 & 4.75 & 188 & 4.98 & 151 & 4.91 & 146 & 4.78 & 370 & 4.69 & $\overline{478}$ \\
\hline 10 & 4.95 & 178 & 4.90 & 174 & 4.99 & 155 & 4.90 & 191 & 5.21 & 139 & 5.11 & 156 & 4.87 & 414 & 4.89 & 495 \\
\hline 40 & 4.94 & 73.0 & 4.96 & 164 & 4.98 & 179 & 5.01 & 79.6 & 5.26 & 133 & 5.15 & 149 & 4.92 & 395 & 4.92 & 464 \\
\hline 80 & 5.02 & 175 & 4.96 & 167 & 5.05 & 176 & 5.06 & 168 & 5.23 & 138 & 5.23 & 136 & 4.78 & 393 & 4.90 & 456 \\
\hline LSD $_{0.05}$ & 0.07 & 19.5 & 0.07 & 18.3 & 0.07 & 31.6 & 0.09 & 13.7 & 0.06 & 8.6 & 0.06 & 10.8 & 0.06 & 35.0 & 0.04 & 21.9 \\
\hline
\end{tabular}

Table 4. Coefficients of determination $\left(R^{2}\right)$ for the multiple regression between clipping yield, tissue $\mathrm{P}$, or $\mathrm{P}$ uptake and $\mathrm{NaHCO}_{3}$ extractable $\mathrm{P}$ and exchangeable $\mathrm{Ca}$ (ECa) for creeping bentgrass and annual bluegrass in four soils.

\begin{tabular}{|c|c|c|c|c|c|c|c|}
\hline \multirow[b]{3}{*}{ Soil } & \multirow[b]{3}{*}{$\begin{array}{l}\text { Independent } \\
\text { variable }\end{array}$} & \multicolumn{6}{|c|}{$R^{2 \mathrm{z}}$} \\
\hline & & \multicolumn{3}{|c|}{ Creeping bentgrass } & \multicolumn{3}{|c|}{ Annual bluegrass } \\
\hline & & $\begin{array}{l}\text { Clipping } \\
\text { yield }\end{array}$ & $\begin{array}{c}\text { Tissue } \\
\mathrm{P}\end{array}$ & $\begin{array}{c}\mathbf{P} \\
\text { uptake }\end{array}$ & $\begin{array}{l}\text { Clipping } \\
\text { yield }\end{array}$ & $\begin{array}{c}\text { Tissue } \\
\mathrm{P}\end{array}$ & $\begin{array}{c}\mathbf{P} \\
\text { uptake }\end{array}$ \\
\hline \multirow[t]{2}{*}{ Papac } & $\mathrm{NaHCO}_{3}-\mathrm{P}$ & 0.56 & 0.67 & 0.73 & 0.80 & 0.89 & 0.92 \\
\hline & $\mathrm{NaHCO}_{3}^{3}-\mathrm{P}, \mathrm{ECa}$ & 0.56 & 0.89 & 0.90 & 0.80 & 0.89 & 0.92 \\
\hline \multirow[t]{2}{*}{ Wishkah } & $\mathrm{NaHCO}_{3}^{3} \mathrm{P}$ & 0.71 & 0.89 & 0.86 & 0.67 & 0.71 & 0.80 \\
\hline & $\mathrm{NaHCO}_{3}-\mathrm{P}, \mathrm{ECa}$ & 0.71 & 0.93 & 0.86 & 0.74 & 0.71 & 0.80 \\
\hline \multirow{2}{*}{ Calawah } & $\mathrm{NaHCO}_{3}^{3}-\mathrm{P}$ & 0.62 & 0.87 & 0.87 & 0.73 & 0.78 & 0.84 \\
\hline & $\mathrm{NaHCO}_{3}-\mathrm{P}, \mathrm{ECa}$ & 0.62 & 0.87 & 0.87 & 0.73 & 0.78 & 0.86 \\
\hline \multirow[t]{2}{*}{ Mopang } & $\mathrm{NaHCO}_{3}-\mathrm{P}$ & 0.57 & 0.89 & 0.86 & 0.77 & 0.88 & 0.90 \\
\hline & $\mathrm{NaHCO}_{3}-\mathrm{P}, \mathrm{ECa}$ & 0.57 & 0.90 & 0.87 & 0.77 & 0.88 & 0.90 \\
\hline
\end{tabular}

${ }^{\overline{ }}$ All $R^{2}$ values are significant at $P \leq 0.001$.

Table 5. Clipping yields, tissue $\mathrm{P}$, and $\mathrm{P}$ uptake of creeping bentgrass and annual bluegrass as affected by P. Averaged over soils and $\mathrm{Ca}$ rates.

\begin{tabular}{lllrr}
\hline \hline $\begin{array}{l}\text { Prate } \\
\left(\mathrm{mg} \cdot \mathrm{kg}^{-1}\right)\end{array}$ & \multicolumn{1}{c}{$\begin{array}{c}\text { Grass } \\
\text { species }\end{array}$} & $\begin{array}{c}\text { Clipping } \\
\text { yield } \\
(\mathrm{g} / \mathrm{pot})\end{array}$ & $\begin{array}{c}\text { Tissue } \\
\mathrm{P} \\
\left(\mathrm{mg}^{-1} \cdot \mathrm{kg}^{-1}\right)\end{array}$ & $\begin{array}{c}\mathbf{P} \\
\text { uptake } \\
(\mathrm{mg} / \mathrm{pot})\end{array}$ \\
\hline 0 & Creeping bentgrass & $0.179 \mathrm{a}$ & $1301 \mathrm{a}$ & $0.235 \mathrm{a}$ \\
& Annual bluegrass & $0.089 \mathrm{~b}$ & $796 \mathrm{~b}$ & $0.084 \mathrm{~b}$ \\
10 & Creeping bentgrass & $0.529 \mathrm{a}$ & $2053 \mathrm{a}$ & $1.077 \mathrm{a}$ \\
& Annual bluegrass & $0.492 \mathrm{a}$ & $2022 \mathrm{a}$ & $1.014 \mathrm{a}$ \\
40 & Creeping bentgrass & $0.604 \mathrm{~b}$ & $3188 \mathrm{a}$ & $1.914 \mathrm{~b}$ \\
& Annual bluegrass & $0.729 \mathrm{a}$ & $3139 \mathrm{a}$ & $2.292 \mathrm{a}$ \\
80 & Creeping bentgrass & $0.642 \mathrm{~b}$ & $4224 \mathrm{a}$ & $2.723 \mathrm{a}$ \\
& Annual bluegrass & $0.757 \mathrm{a}$ & $4114 \mathrm{a}$ & $3.144 \mathrm{~b}$ \\
\hline
\end{tabular}

${ }^{2}$ Mean separation within each $\mathrm{P}$ treatment at $P \leq 0.05$.

effect on exchangeable soil Al was small, a result that is consistent with the findings of Perkins and Kaihulla (1981) and Alva et al. (1990). If a large reduction of exchangeable $\mathrm{Al}$ by $\mathrm{CaSO}_{4}$ occurs, it would be difficult to isolate specific effects of $\mathrm{Ca}$, particularly on $\mathrm{P}$ use by these two grasses. Aluminum is known to interfere with $\mathrm{P}$ translocation and use by plants (Jensen et al., 1989) and affect plant growth (Blair et al., 1988; Kuo et al., 1991).

Adding $\mathrm{P}$ increased soil $\mathrm{pH}$ and reduced exchangeable soil Al slightly (Table 3 ). Such a phenomenon is often observed in acidic soils receiving some $\mathrm{P}$ and may be attributable to the increased surface negative charge by $\mathrm{P}$ sorption (Ryden and Syers, 1975) and the replacement of some surface $\mathrm{OH}^{\text {by }}$ bhosphate ion through ligand exchange (Pardo and Guadalix, 1990).

Plant growth characteristics. Clipping yields of both grasses responded to increased $\mathrm{NaHCO}_{3}$-P levels (Fig. 1). More than $56 \%$ of the variability in clipping yield was accounted for by $\mathrm{NaHCO}_{3}-\mathrm{P}$ (Table 4). The effect of adding $\mathrm{Ca}$ on clipping yields was small for either grass, as including exchangeable $\mathrm{Ca}$ with $\mathrm{NaHCO}_{3}-\mathrm{P}$ in multiple regressions failed to account for additional variability in clipping yield. Annual bluegrass clipping yield was significantly higher than that of creeping bentgrass at high $\mathrm{P}$ rates (40 and $80 \mathrm{mg} \cdot \mathrm{kg}^{-1}$ ) (Table 5); this result indicates that annual bluegrass is as tolerant of moderate levels of soil acidity and exchangeable $\mathrm{Al}$ as creeping bentgrass, provided that available $\mathrm{P}$ in the soils is adequate. The level of soil available $\mathrm{P}$, rather than the moderate levels of acidity and exchangeable $\mathrm{Al}$, controls the growth of the two grasses in these soils.

The clipping tissue $\mathrm{P}$ concentrations and $\mathrm{P}$ uptake, like clipping yields, were controlled mainly by $\mathrm{NaHCO}_{3}$-P levels (Figs. 2 and 3). The $\mathrm{NaHCO}_{3}-\mathrm{P}$ accounted for $>67 \%$ of the variabilities in tissue $P$ concentrations of both grasses (Table 4). Increasing available $\mathrm{Ca}$ by adding $\mathrm{CaSO}_{4}$ markedly increased the tissue $\mathrm{P}$ and $\mathrm{P}$ uptake by bentgrass in the Papac soil, which contained the least amount of exchangeable $\mathrm{Ca}$ (Table 1). In this soil, the inclusion of exchangeable $\mathrm{Ca}$ with $\mathrm{NaHCO}_{3}-\mathrm{P}$ in the multiple regression increased the variability accounted for from 0.67 to 0.89 for tissue $\mathrm{P}$ and from 0.73 to 0.90 for P uptake (Table 4). With no similar responses for annual bluegrass, we presume that annual bluegrass had a lower $\mathrm{Ca}$ requirement than bentgrass. Including exchangeable $\mathrm{Ca}$ with $\mathrm{NaHCO}_{3}$-P was less effective in accounting for variability in creeping bentgrass tissue $\mathrm{P}$ for the Wishkah soil and accounted for no variability for the Calawah or Mopang soil that contained higher exchangeable Ca (Table 1).

While zero $\mathrm{P}$ treatment or low $\mathrm{NaHCO}_{3}-\mathrm{P}$ levels favored creeping bentgrass over annual bluegrass in clipping tissue $\mathrm{P}$ concentration and $\mathrm{P}$ uptake, the trend for $\mathrm{P}$ uptake was reversed at high $\mathrm{P}$ rates (Table 5) or high $\mathrm{NaHCO}_{3}$-P levels (Fig. 2). In conjunction with the clipping yield results, this substantiates the earlier findings of Goss et al. (1975) and Waddington et al. (1978) that high soil P 

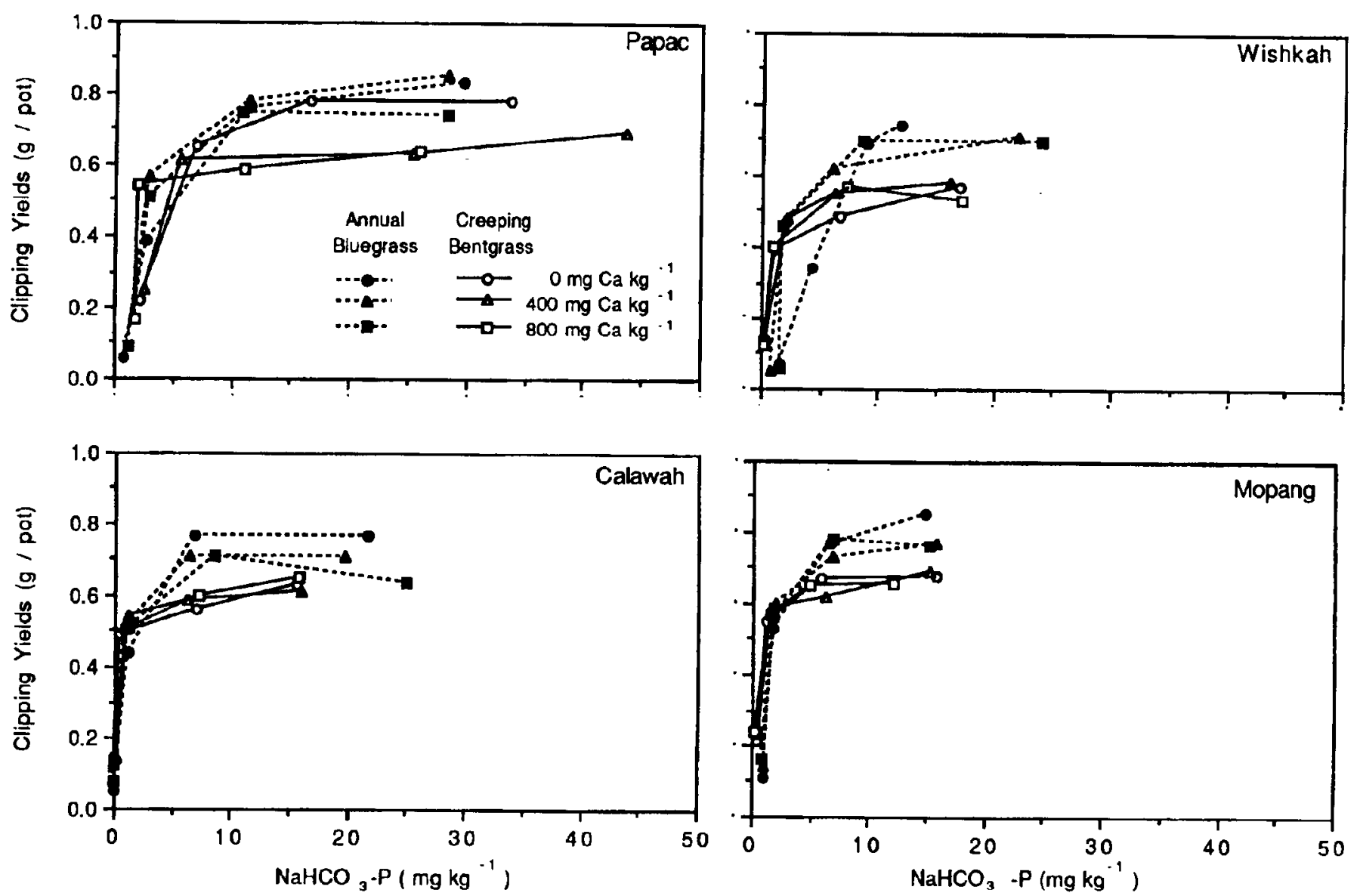

Fig. 1. Clipping yield response of creeping bentgrass or annual bluegrass to $\mathrm{NaHCO}_{3}-\mathrm{P}$ in four acid soils as affected by Ca rates $\left(0,400\right.$, or $\left.800 \mathrm{mg} \cdot \mathrm{kg}^{-1}\right)$.
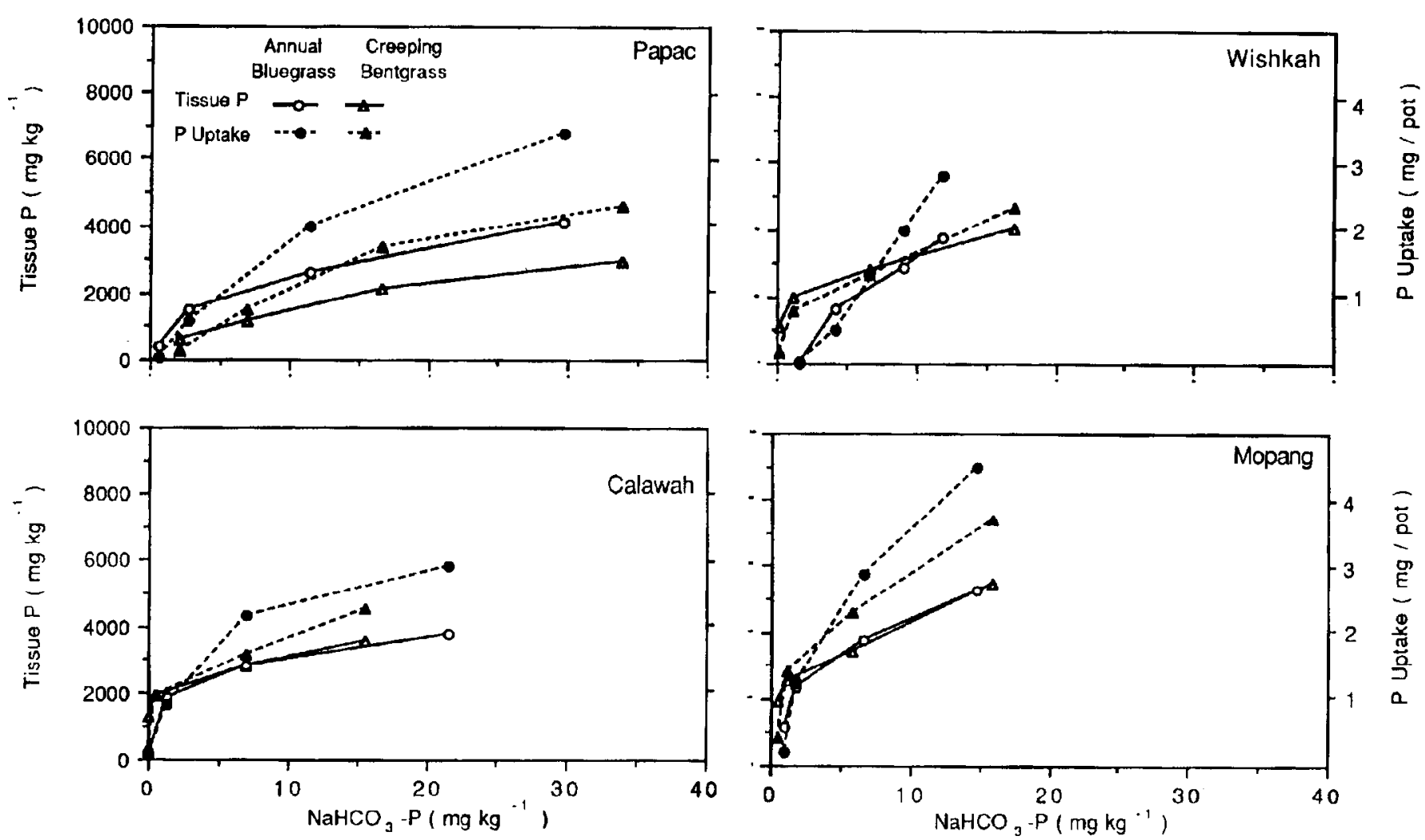

Fig. 2. Response of clipping $\mathrm{P}$ concentration or $\mathrm{P}$ uptake of creeping bentgrass or annual bluegrass to $\mathrm{NaHCO}_{3}-\mathrm{P}$ in four acid soils. 

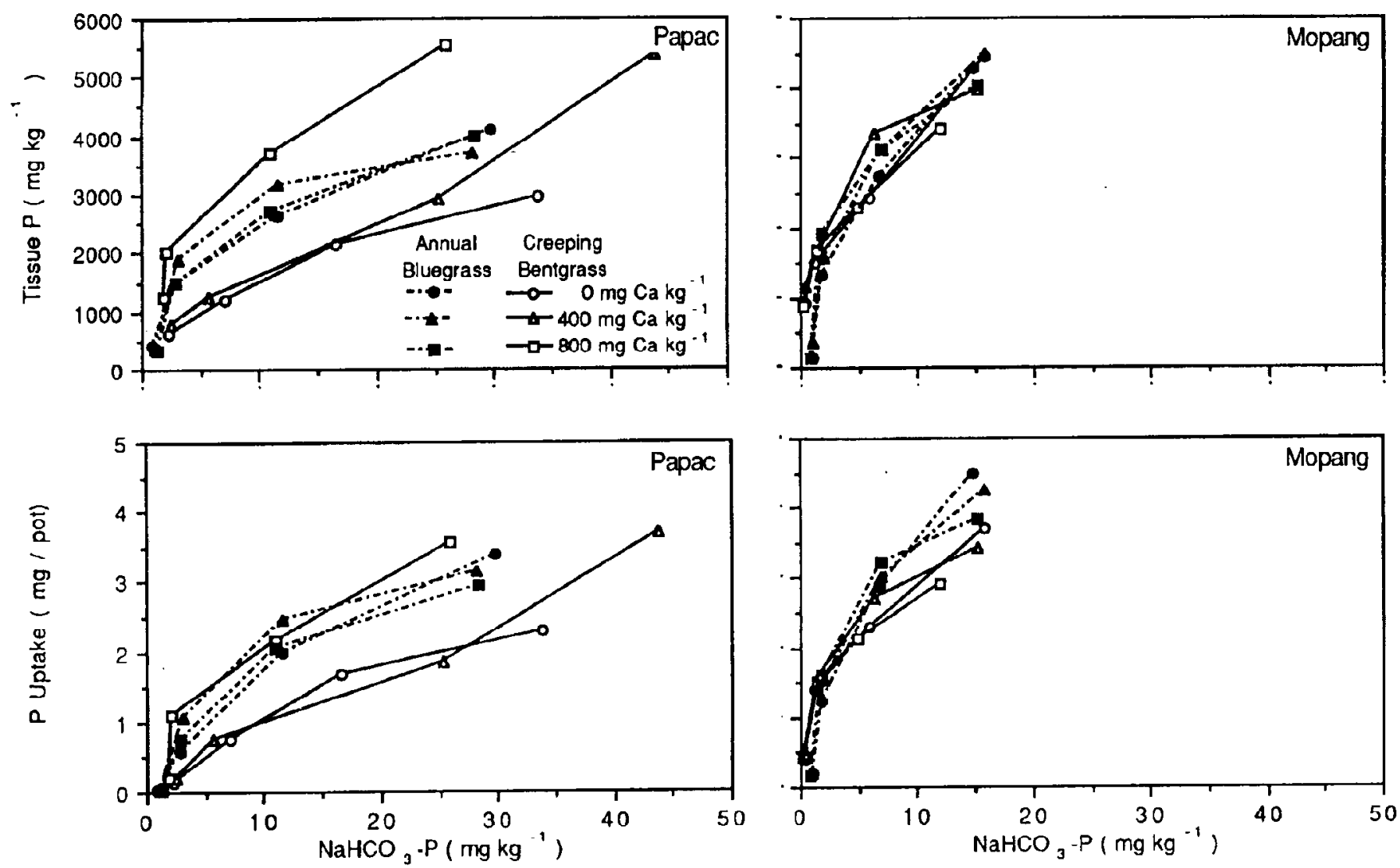

Fig. 3. Effect of Ca rates $\left(0,400\right.$, or $\left.800 \mathrm{mg} \cdot \mathrm{kg}^{-1}\right)$ on clipping $\mathrm{P}$ concentration and $\mathrm{P}$ uptake of creeping bentgrass or annual bluegrass in Papac or Mopang soil.

availability is conducive to annual bluegrass growth.

The above results clearly illustrate that, while annual bluegrass is more responsive to available $\mathrm{P}$, creeping bentgrass is more responsive to available $\mathrm{Ca}$ for the soils studied. The latter should be considered in developing $\mathrm{P}$ fertilization and soil acidification practices to control infestation of bentgrass by annual bluegrass. Calcium leaching from soil commonly occurs when soil is acidified. Maintaining adequate exchangeable $\mathrm{Ca}$ by adding $\mathrm{CaSO}_{4}$ or other Ca-containing fertilizers [e.g., $\mathrm{Ca}\left(\mathrm{NO}_{3}\right)_{2}$ ] may be necessary, particularly for soils that have low $\mathrm{Ca}$ availability before being acidified.

\section{Literature Cited}

Alva, A.K., M.E. Sumner, and W.P. Miller. 1990. Reactions of gypsum or phosphogypsum in highly weathered acid subsoils. Soil Sci. Soc. Amer. J. 54:993-998.

Berry, D.F., L.W. Zelazny, and H.L. Walker, Jr. 1990. Aluminum and organic matter mobilization from forest soil infiltrated with acidified calcium sulfate. Soil. Sci. Soc. Amer. J. 54: 17571782.

Blair, G.J., K.B. Lithgow, and P.W. Ochard. 1988. The effects of $\mathrm{pH}$ and calcium on the growth of Leucaena leucocephala in an oxisol and ultisol soil. Plant Soil 106:209-214.

Goss, R.L., S.E. Brauen, and S.P. Orton. 1975. The effect of N, P, and K, and S on Poa annua L. in bentgrass putting green turf. J. Sports Turf Res. Inst. 51:74-82.

Jensen, P., S. Pettersson, T. Drakenberg, and H. Asp. 1989. Aluminum effects on vacuolar phosphorus in roots of beech (Fagus sylvatica L.). J. Plant Physiol. 134:37-42.

Kuo, S., S.E. Brauen, and E.J. Jellum. 1991. The effects of aluminum and phosphate on the growth of annual bluegrass and bentgrass in some acidic western Washington soils. Soil Sci. 153:365372.

Miller, R.J., J.H. Peverly, and D.E. Koeppe. 1972. Calcium-stimulated ${ }^{32} \mathrm{P}$ accumulation by corn roots. Agron. J. 64:262-266.

Murphy, J. and J.P. Riley. 1962. A modified single solution method for the determination of phosphate in natural water. Anal. Chim. Acta 27:3136.

Nittler, L.W. and T.J. Kenny. 1972. Cultivar differences among calcium-deficient Kentucky blue- grass seedlings. Agron. J. 64:73-75.

Olsen, S.R. and L.E, Sommers, 1982. Phosphorus, p. 403-430. In: A.L. Page et al. (eds.). Methods of soil analysis. part 2. Agronomy 9. Amer. Soc. Agron., Madison, Wis.

Pardo, M.T. and M.E. Guadalix. 1990. Phosphate sorption in allophonic soils and release of sulfate, silicate and hydroxyl. J. Soil Sci. 41:607612.

Pavan, M.A., F.T. Bingham, and P.F. Praft, 1984. Redistribution of exchangeable calcium magnesium, and aluminum following lime or gypsum applications to a Brazilian Oxisol. Soil Sci. Soc. Amer. J, 48:33-38.

Perkins, H.F. and E. Kaihulla. 1981. Some characteristics of Plinthite inhibiting plant growth. Agron. J. 73:671-673.

Ryden, J.C. and J.K. Syers. 1975. Charge relationships of phosphate sorption. Nature 255:5 1-53.

Varco, J.J. and J.B. Sartain, 1986. Effects of phosphorus, sulfur, calcium hydroxide, and $\mathrm{pH}$ on growth of annual bluegrass. Soil Sci. Soc. Amer. J. 50:128-132.

Waddington, D.V., T.R. Turner, J.M. Duich, and E.L. Moberg. 1978. Effect of fertilization on Penncross creeping bentgrass. Agron. J. 70:713718. 